\title{
Edmund Burke and Reason of State
}

\section{Citation}

Armitage, David. 2000. Edmund Burke and reason of state. Journal of the History of Ideas 61(4): 617-634.

\section{Published Version}

http://dx.doi.org/10.1353/jhi.2000.0033

\section{Permanent link}

http://nrs.harvard.edu/urn-3:HUL.InstRepos:3373615

\section{Terms of Use}

This article was downloaded from Harvard University's DASH repository, and is made available under the terms and conditions applicable to Other Posted Material, as set forth at http:// nrs.harvard.edu/urn-3:HUL.InstRepos:dash.current.terms-of-use\#LAA

\section{Share Your Story}

The Harvard community has made this article openly available.

Please share how this access benefits you. Submit a story.

Accessibility 


\title{
Edmund Burke and Reason of State
}

\author{
David Armitage
}

Edmund Burke has been one of the few political thinkers to be treated seriously by international theorists. ${ }^{1}$ According to Martin Wight, one of the founders of the so-called "English School" of international theory, Burke was "[ $t]$ he only political philosopher who has turned wholly from political theory to international theory."2 The resurgence of interest in Burke as an international theorist has not, however, generated any consensus about how he might be classified within the traditions of international theory. Wight variously divided thinkers into trichotomous schools of Realists, Rationalists, and Revolutionaries, Machiavellians, Grotians, and Kantians, or theorists of international anarchy, habitual intercourse, or moral solidarity; ${ }^{3}$ more recent international theorists have refined or supplemented these categories to construct similar trinitarian traditions of Realism, Liberalism, and Socialism, and of Empirical Realism, Universal Moral Order, and Historical Reason. ${ }^{4}$ Burke's place within any of these traditions remains uncertain. Debate over whether he was a realist or an idealist, a

My thanks to Jack Censer, Istvan Hont, Susan Marks, Darrin McMahon, Julia Rudolph, and especially Jeremy Waldron for their comments on earlier versions of this essay.

${ }^{1}$ See David P. Fidler and Jennifer M. Welsh (eds.), Empire and Community: Edmund Burke's Writings and Speeches on International Relations (Boulder, 1999).

${ }^{2}$ Martin Wight, "Why is There No International Theory?" Diplomatic Investigations: Essays in the Theory of International Politics, ed. Herbert Butterfield and Martin Wight (London, 1966), 20; on whom see Tim Dunne, Inventing International Society: A History of the English School (Houndmills, 1998), 47-63.

${ }^{3}$ Martin Wight, International Theory: The Three Traditions, ed. Gabriele Wight and Brian Porter (London, 199 $\rightarrow$ Wight, "An Anatomy of International Thought," Review of International Studies, 13 (1987), 221- $\rightarrow$ Hedley Bull, "Martin Wight and the Theory of International Relations," British Journal of International Studies, 2 (1976), 101-16 (repr. Wight, International Theory, ed. Gabriele Wight and Porter, ix-xxiii); Brian Porter, "Patterns of Thought and Practice: Martin Wight's 'International Theory,' "The Reason of States: A Study in International Political Theory, ed. Michael Donelan (London, 1978), 64-74.

${ }^{4}$ Michael W. Doyle, Ways of War and Peace: Realism, Liberalism, and Socialism (New York, 1997), 18-20, and passim; David Boucher, Political Theories of International Relations: From Thucydides to the Present (Oxford, 1998), 28-43, and passim. 
Rationalist or a Revolutionist, has concluded variously that he was a "conservative crusader" or an "historical empiricist," a belated dualist or a Cold Warrior before the fact, or, most egregiously, "a proto-Marxist, or more precisely protoGramscian" theorist of hegemony. ${ }^{5}$ The fact that Burke so obviously eludes definition may put in doubt the analytical utility of closely-defined "traditions" of international theory. ${ }^{6}$

Burke's relationship to conceptions of reason of state provides a more precise example of the confusion within such taxonomies. According to one recent historian of international theory, Burke "laid the foundations" of the "conservative approach to International Relations informed by the two modern notions of state interest and necessity, by raison d'état"; however, in the words of another, "Burke ... was vehemently opposed to the idea of Reason of State and did not subscribe to the view that national interests override moral laws." 7 The assumptions on which each of these judgments rests are clearly incompatible: on the one hand that a "conservative approach" in the realm of foreign affairs implies an espousal of reason of state defined as the primacy of "state interest and necessity," that Burke did indeed acknowledge; on the other hand that reason of state is defined more exactly as "the view that national interests override moral laws" and that Burke did not hold such a view, so could not be defined as a reason-ofstate theorist. It might of course be possible that Burke held various views on such matters at various points in his long literary and political career or that he argued for differing conceptions of reason of state in differing contexts. To test such a hypothesis demands a historical account of Burke's relationship to the theories of reason of state held by his contemporaries and predecessors.

R. J. Vincent, "Edmund Burke and the Theory of International Relations," Review of International Studies, 10 (1984), 205- $\rightarrow$ David Boucher, "The Character of the History of Philosophy of International Relations and the Case of Edmund Burke," Review of International Studies, 17 (1991), 127-48; Boucher, Political Theories of International Relations, 308-29; Vilho Harle, "Burke the International Theorist - or the War of the Sons of Light and the Sons of Darkness," European Values in International Relations, ed. Vilho Harle (London, 1990), 59, 72; Kenneth W. Thompson, Fathers of International Thought: The Legacy of Political Theory (Baton Rouge, 1994), 100; Fred Halliday, Rethinking International Relations (London, 1994), 108-13. (Thanks to Anders Stephanson for this last reference.)

${ }^{6}$ Jennifer M. Welsh, Edmund Burke and International Relations (London, 1995), 6-9, 172-80; Welsh, "Edmund Burke and the Commonwealth of Europe: The Cultural Bases of International Order," Classical Theories of International Relations, eds. Ian Clark and Iver B. Neumann (Houndmills, 1996), 173-77, 183-86; Empire and Community, ed. Fidler and Welsh, 38-39, 51-56; and see Traditions of International Ethics, eds. Terry Nardin and David R. Mapel (Cambridge, 19؟्) Timothy Dunne, "Mythology or Methodology? Traditions in International Theory," Review of International Studies, 19 (1993), 305-18; Ian Clark, "Traditions of Thought and Classical Theories of International Relations," Classical Theories of International Relations, eds. Clark and Neumann, 1-19.

${ }^{7}$ Torbjörn L. Knutsen, A History of International Relations Theory: An Introduction (Manchester, 1992), 141, 143; Boucher, Political Theories of International Relations, 14. 
To place Burke within traditions of reason of state might seem to be a simple category error. After all, he famously scorned "dashing Machiavellian politicians," deplored "the odious maxims of a Machiavellian policy," condemned "the dreadful maxim of Machiavel that in great affairs men are not to be wicked by halves," and identified the Discorsi as the inflammatory textbook of French republicanism. ${ }^{8}$ His strictures on Machiavelli and Machiavellianism affirmed avant la lettre the classic modern account of reason of state offered by Friedrich Meinecke, which counterposed "raison d'état on the one hand, and ethics and law on the other" and traced the emergence of this separation to the heathen Florentine who had given the tradition its familiar nickname. ${ }^{9}$ Such accounts of reason of state and of Machiavelli reinforced the long-standing interpretation of Burke as the last of the medieval theorists of natural law, for whom no merely human calculations of advantage or interest could override the dictates of divine reason. If reason of state represented the doctrine that political expediency should supersede moral law, then Burke could only have been its (and Machiavelli's) enemy: his "politics ... were grounded on recognition of the universal law of reason and justice ordained by God as the foundation of a good community. In this recognition the Machiavellian schism between politics and morality is closed, and it is exactly in this respect that Burke stands apart from the modern positivists and pragmatists who in claiming him have diminished him." ${ }^{10}$ To accept otherwise would have allowed him to fall back into the hands of those exponents of expediency, the utilitarians and the secularists.

These accounts of reason of state and of natural law arguably depended upon a misapprehension of the modern natural law theory to which Burke was heir. That theory, revived initially by Hugo Grotius and elaborated by his successors, took its foundational principle of self-preservation from the Stoics. To determine the limits of self-preservation as a practical principle always demanded

${ }^{8}$ Edmund Burke, Reflections on the Revolution in France (1790), in The Writings and Speeches of Edmund Burke, ed. L. G. Mitchell, VIII, The French Revolution 1790-1794 (Oxford, 1989), 60, 132; Burke, Fourth Letter on a Regicide Peace (1795-96), in R. B. McDowell (ed.), The Writings and Speeches of Edmund Burke, ed. R. B. McDowell, IX, I: The Revolutionary War 1794-1797; II: Ireland (Oxford, 1991), 69 (alluding to Machiavelli, Discorsi, I. 27); Burke, Second Letter on a Regicide Peace (1796), Writings and Speeches, ed. McDowell, IX, 282.

${ }^{9}$ Friedrich Meinecke, Machiavellism: The Doctrine of Raison d'État and Its Place in Modern History, tr. Douglas Scott, intro. Werner Stark (New Brunswick, 1998), 28, 29. In Cosmopolitanism and the Nation State, tr. Robert B. Kimber (Princeton, 1970), 101, Meinecke had argued that Burke "struck the first decisive blow against conceptions of the state that the eighteenth century had formed on the basis of natural law" and assimilated him to Machiavelli and later advocates of Realpolitik who had also recognized the importance of "the irrational components of the life of the state, for the power of traditions, customs, instinct, and impulsive feelings."

${ }^{10}$ Burke's Politics: Selected Writings and Speeches of Edmund Burke on Reform, Revolution, and War, Ross J. Hoffman and Paul Levack (New York, 1949), xv. 
calculations of competing goods according to consequentialist criteria. ${ }^{.1}$ This was true no less for bodies politic and their rulers than it was for private persons. In the political realm the fundamental determining factor in any calculation of outcomes would be necessity. In the case of the res publica necessity, as a principle of political action, could only be justified by an appeal to that salus populi which was the suprema lex, in Cicero's famous words (De Legibus, III, 3 ). Cicero placed severe constraints upon such calculations in the municipal sphere, and restricted them to the ends of self-defense, security, or the protection of liberty; any actions taken in pursuit of such ends had also to avoid infamy and to be in accordance with the republican constitution. ${ }^{12}$ In their later recensions - shorn of the specifically Roman and republican legal context within which Cicero wrote - such theories could reconcile the principles of natural law with strictly limited appeals to necessity in the interests of the common good; they could also be extended beyond the municipal to the international realm. ${ }^{13}$

This "modern" tradition of natural jurisprudence, which rested upon the arguments of Stoic ethics, was utilitarian to the extent that it depended upon the calibration of competing goods in relation to specific ends. To place Burke within the theory of reason of state derived from this tradition implies no inconsistency in his thought. The opponent of "Machiavellian" expediency could equally well be the proponent of Ciceronian "necessity": the difference between the two depended upon the criteria deployed, the circumstances that could be appealed to, and the consequences that were desired or imagined. To situate Burke within this strain of early modern reason of state theory also makes it possible to appreciate just "how much weight [he] attaches to considerations based on expediency, treated simply as a practical regard for consequences." ${ }^{14}$ Moreover, since reason of state within this tradition was consequentialist precisely because it was grounded in a neo-Stoic conception of natural law, to see Burke as a reason-ofstate theorist in this context neatly avoids the sterile dispute about the true character of his political thought as either utilitarian or natural jurisprudential. ${ }^{15}$ It could be described as both, so long as the tradition of natural jurisprudence in question was the "modern" one initiated by Grotius and so long as the utilitari-

${ }^{11}$ Richard Tuck, "The 'Modern' Theory of Natural Law," The Languages of Political Theory in Early-Modern Europe, ed. Anthony Pagden (Cambridge, 1987), 99-119; Tuck, Philosophy and Government, 1572-1651 (Cambridge, 1993), 172-76.

${ }^{12}$ Norberto de Sousa, "Cicero on the Themes of Necessity and Public Utility," unpublished paper presented to the Seminar, "The Politics of Necessity and the Language of Reason of State," King's College, Cambridge, 22 January 1993.

${ }^{13}$ Richard Tuck, The Rights of War and Peace: Political Thought and the International Order from Grotius to Kant (Oxford, 1999), 18-23, 29-31.

${ }^{14}$ Donald Winch, Riches and Poverty: An Intellectual History of Political Economy in Britain, 1750-1834 (Cambridge, 1996), 196.

${ }^{15}$ John Dinwiddy, "Utility and Natural Law in Burke's Thought: A Reconsideration," Studies in Burke and His Time, 16 (1974), 107, 123-25. 
anism in question was of this consequentialist kind. The assertion that "the natural-law tradition and consequentialism are opposed at a very deep level" is therefore not true of all forms of natural jurisprudence or even of consequentialism; ${ }^{16}$ nor is it necessary to choose between them to characterize Burke's political or international thought.

Burke's reason-of-state theory could be applied equally to the internal constitution and the external relations of a state. In this way its scope extended beyond the internal political determinations laid down by Cicero to the international realm treated by the "modern" theorists of natural law like Grotius. Reason of state was thus Janus-faced like its conceptual near-neighbors in early modern political thought, sovereignty, and the balance of power. ${ }^{17}$ Like them, reason of state crossed the boundary between political theory, defined as the theory of legitimacy and distribution of power within the state, and international theory. In both spheres reason of state acknowledged the compulsions of necessity; its particular theoretical concern was therefore with the contingent, the extraordinary, and the unforeseeable. "A high degree of causal necessity," argued Meinecke, "which the agent himself is accustomed to conceive as absolute and inescapable, and to feel most profoundly, is part of the very essence of all action prompted by raison d'état." 18 Since necessity has no law (necessitas non habet legem), reason of state could not be codified or legislated. Reason of state alone could not determine which circumstances were truly cases of extreme necessity and hence which precise occasions could permit the overriding of custom and law. It could only lay down norms from which such exceptions could be derived, and more generally it provided a consequentialist means of applying the norms of natural law. In these regards reason of state was close to resistance theory which also dealt with extremity and overwhelming necessity. Resistance theory did, however, lay down stringent conditions under which rebellion might be justified, even if only in retrospect, and offered a wider range of agents the possibility of making judgments of necessity, even to the point of democratic agency. The compulsion of necessity demanded in reason of state theory was assumed to be universally recognizable but only under particular circumstances by specific, usually sovereign, agents. The conditions which would make necessity both evident and compelling could never be defined with any precision; it therefore demanded princely or consiliar discretion for its application. These requirements placed it firmly among the arcana imperii and left it open to the

${ }^{16}$ Pace Joseph Boyle, "Natural Law and International Ethics," in Traditions of International Ethics, eds. Nardin and Mapel, 119; compare Carl Friedrich, Constitutional Reason of State: The Survival of the Constitutional Order (Providence, R.I., 1957), 31-32.

${ }^{17}$ F. H. Hinsley, Sovereignty (Cambridge, 1986²), chs. 4-5; M. S. Anderson, The Rise of Modern Diplomacy, 1450-1919 (London, 1993), 150-54.

${ }^{18}$ Meinecke, Machiavellism, 6 
charge (especially from those who were excluded from judging) that it was merely subjective, arbitrary, and unconstrainable.

Because reason of state, whether municipal or international, was morally ambivalent, two types might legitimately be inferred, one natural and hence justifiable, the other merely putative and hence reprehensible. ${ }^{19}$ The English Whig tradition which preceded Burke and upon which he drew contained examples of these two strains of reason of state. For example, the Marquis of Halifax argued in 1684 that "there is a natural reason of State, an undefinable thing grounded upon the Common good of mankind, which is immortall, and in all changes and Revolutions still preserveth its Originall right of saving a Nation, when the Letter of the Law perhaps would destroy it."20 "Reall Necessity," he later affirmed, "is not to bee resisted, and pretended necessity is not to bee alleadged." 21 Since politicians still alleged necessity nonetheless, it would be distrusted as simply one of the "Arcana Imperii," complained John Toland in 1701, "when in reality Reason of State is nothing else but the right reason of managing the affairs of the State at home and abroad, according to the Constitution of the Government, and with regard to the Interest or Power of other Nations."22 The difficulty of judging whether reason of state was natural and directed legitimately towards the interest of the community, or contrived for the benefit of the rulers alone, made it both contestable and open to apparently opposing constructions, even within the thought of a single theorist. As Burke himself noted in his Third Letter on a Regicide Peace (1796-97), "Necessity, as it has no law, so it has no shame; but moral necessity is not like metaphysical, or even physical. In that category, it is a word of loose signification, and conveys different ideas to different minds." ${ }^{23}$

Burke's engagement with the language of reason of state ran from his first published political work, the Vindication of Natural Society (1756), to the last, the Third Letter on a Regicide Peace. In this he remarked in passing that "reason of state and common-sense are two things"; 24 thirty years earlier, in the Vindication, he had satirized contemporary consequentialism along the same lines:

${ }^{19}$ Maurizio Viroli, From Politics to Reason of State: The Acquisition and Transformation of the Language of Politics 1250-1600 (Cambridge, 1992), 273-74.

${ }^{20}$ George Savile, Marquis of Halifax, The Character of a Trimmer (1684), in The Works of George Savile Marquis of Halifax, ed. Mark N. Brown (3 vols.; Oxford, 1989), I, 191.

${ }^{21}$ Halifax, "Prerogative" (1685-88?), in Works of George Savile Marquis of Halifax, ed. Brown, II, 41.

${ }^{22}$ [John Toland,] The Art of Governing by Partys (London, 1701), 93-94.

${ }^{23}$ Burke, Third Letter on a Regicide Peace (1796-97), in Writings and Speeches, ed. McDowell, IX, 344.

${ }^{24}$ Burke, Third Letter on a Regicide Peace, in Writings and Speeches, ed. McDowell, IX, 300 . 
All Writers on the Science of Policy are agreed, and they agree with Experience, that all Governments must frequently infringe the Rules of Justice to support themselves; that Truth must give way to Dissimulation; Honesty to Convenience; and Humanity itself to the reigning Interest. The Whole of this Mystery of Iniquity is called the Reason of State. It is a Reason, which I own I cannot penetrate. What Sort of a Protection is this of the general Right, that is maintained by infringing the Rights of Particulars? What sort of Justice is this, which is inforced by Breaches of its own Laws? ... For my part, I say what a plain Man would say on such an Occasion. I can never believe, that any Institution agreeable to Nature, and proper for Mankind, could find it necessary, or even expedient in any Case whatsoever to do, what the best and worthiest Instincts of Mankind warn us to avoid. ${ }^{25}$

The publication of Bolingbroke's deistic writings in 1754 and of Rousseau's second Discourse in 1755 provided the immediate targets for the Vindication's ironic attempt to undermine arguments in favor of natural religion by reducing equivalent arguments for natural society ad absurdum. ${ }^{26}$ However, Burke's target in this passage of the Vindication was neither Bolingbroke nor Rousseau but Hume. In the Treatise of Human Nature (1739-40) Hume had argued that the laws of nations did not supersede the laws of nature. Both persons and bodies politic were bound by the same duties to uphold property and promises; however, the obligation is weaker for princes than for private persons: "the morality of princes has the same extent, yet it has not the same force as that of private persons," in proportion to the advantages to be gained by nations rather than individuals from security of property, the administration of justice, and the adjudication of equity, he argued. ${ }^{27}$ When Hume returned to this question in the Enquiry Concerning the Principles of Morals (1751), he restated the distinction in the language of reason of state and provided the immediate occasion for Burke's satire in the Vindication:

${ }^{25}$ [Burke,] A Vindication of Natural Society (1756), in The Writings and Speeches of Edmund Burke, ed. T. O. McLoughlin and James T. Boulton, I, The Early Writings (Oxford, 1997), 154. Cf. Rousseau's almost exactly contemporaneous remarks in "The State of War" ( $c$. 1755-56), in Rousseau: The Social Contract and Other Later Political Writings, ed. Victor Gourevitch (Cambridge, 1997), 163: "according to the ideas of princes about their absolute independence, force alone, speaking to citizens in the guise of law and foreigners in the guise of reason of state, deprives the latter of the power and the former of the will to resist, so that everywhere the vain name of justice only serves as a shield for violence."

${ }^{26}$ J. C. Weston, Jr., "The Ironic Purpose of Burke's Vindication Vindicated," JHI, 19 (1958), 435-41; Burke: Pre-Revolutionary Writings, ed. Ian Harris (Cambridge, 1993), 4-6.

${ }^{27}$ David Hume, A Treatise of Human Nature (1739-40), L. A. Selby-Bigge and P. H. Nidditch (Oxford, 1978²), 567-68 (III. ii. 11, "Of the laws of nations"). 
The observance of justice, though useful among [nations], is not guarded by so strong a necessity as it is among individuals; and the moral obligation holds proportion with the usefulness. All politicians will allow, and most philosophers, that REASON OF STATE may, in particular emergencies, dispense with the rules of justice, and invalidate any treaty or alliance, where the strict observance of it would be prejudicial, in a considerable degree, to either of the contracting parties. But nothing less than the most extreme necessity, it is confessed, can justify individuals in a breach of promise, or an invasion of the properties of others. $^{28}$

Burke's ironic recension of Hume left the theoretical foundations of this argument for acting in accordance with reason of state unscathed. Only if civil society itself were illegitimate would such reason of state be unconscionable. If, as Burke later argued in the Reflections, government was a necessary "contrivance of human wisdom to provide for human wants" and if "men have a right that these wants should be provided for by this wisdom," it followed that government was empowered to provide for those wants by any necessary means: the individual members of civil society had already resigned to the government their "right of self-defense, the first law of nature," and had therefore ceded adjudications of necessity to their governors. ${ }^{29}$

Even within the municipal sphere, Burke argued, any law might be suspended, though only under the compulsion of extreme necessity and in the interest of the preservation of the political community. Conor Cruise O'Brien has taken such an admission to be "one of those distressing matters, abounding in the Burkean universe, for which some arrangement of veils was normally appropriate." ${ }^{30}$ However, the principle seems to have caused Burke little distress and would hardly have been a revelation to him. As he told the House of Commons in 1780, the great patent offices in the Exchequer could not be swept away in the name of Economical Reform because, as offices held for life, they were a species of property and only necessity could override the principle of legitimate possession. "There are occasions of publick necessity, so vast, so clear, so evident," he nevertheless admitted, "that they supersede all laws. Law being made only for the benefit of the community, no law can set itself up against the cause and

${ }^{28}$ David Hume, An Enquiry concerning the Principles of Morals (1751), ed. Tom L. Beauchamp (Oxford, 1998), 100 (Section IV, "Of Political Society").

${ }^{29}$ Burke, Reflections on the Revolution in France, in Writings and Speeches, ed. Mitchell, VIII, 110; and see Iain Hampsher-Monk, "Burke and the Religious Sources of Skeptical Conservatism," in The Skeptical Tradition Around 1800: Skepticism in Philosophy, Science, and Society, ed. Johan Van der Zande and Richard H. Popkin (Dordrecht, 1998), 235-59.

${ }^{30}$ Conor Cruise O’Brien, The Suspecting Glance (London, 1972), 34-35. 
reason of all law."31 Only such overmastering compulsion, defined in accordance with public necessity (the Ciceronian utilitas publica or utilitas rei publica), could justify an appeal to reason of state. On the same grounds, he charged that the Protestant Association's opposition to Catholic relief, which they "dignified by the name of reason of state, and security for constitutions and commonwealths" was a mere "receipt of policy, made up of a detestable compound of malice, cowardice, and sloth," and hence not a legitimate invocation of the principle. ${ }^{32}$ Because the appeal to necessity was only justifiable for the benefit of the whole community and ultimately the preservation of society itself, the occasions on which it could legitimately be invoked had to be extraordinary and overmastering: as Burke argued consistently during the impeachment of Warren Hastings, it could therefore not be raised into a regular principle of government. $^{33}$

Burke argued that only the Glorious Revolution fulfilled these exacting conditions in recent English history and hence provided a reliable standard against which to judge later claims of public necessity. Richard Price's assertion that 1688 had made cashiering kings a regular principle of the British constitution forced Burke to refine this theory of state necessity. Against Price, Burke argued that the Revolution had been "an act of necessity, in the strictest moral sense in which necessity can be taken," and that it could not therefore be erected into a constitutional precedent. The extremity of the situation showed that it was possible "to reconcile the use of both a fixed rule and an occasional deviation" and that this was the only way to remedy such an emergency without a complete dissolution of government. ${ }^{34}$ This argument resuscitated a Tory means to defend the Whig doctrine of the ancient constitution in the aftermath of 1688 ; by adopting it Burke was also following the lead of the nervous Whig prosecutors of Henry Sacheverell in 1712. ${ }^{35}$ This particular argument from necessity had first been employed as a justification of the Revolution by Tories such as Edmund

${ }^{31}$ Edmund Burke, "Speech on Presenting to the House of Commons, a Plan for the Better Security of the Independence of Parliament, and the Economical Reformation of the Civil and Other Establishments" (1780), in The Works of the Right Honourable Edmund Burke (16 vols.; London, 1803-27), III, 308-9.

${ }^{32}$ Edmund Burke, "Speech at the Guildhall in Bristol, Previous to the Late Election in that City, Upon Certain Points Relative to his Parliamentary Conduct" (1780), in Works of Edmund Burke, III, 418.

${ }^{33}$ Carl B. Cone, Edmund Burke and the Nature of Politics (2 vols.; Lexington, Ky., 195764), II, 205-7; W. H. Greenleaf, "Burke and State Necessity: The Case of Warren Hastings," Staatsräson: Studien zur Geschichte eines politischen Begriff, ed. Roman Schnur (Berlin, 1975), 549-67; Frederick G. Whelan, Edmund Burke and India: Political Morality and Empire (Pittsburgh, 1996), 188-93, 199-202.

${ }^{34}$ Richard Price, A Discourse on the Love of our Country (London, 17893), 34; Burke, Reflections on the Revolution in France, in Mitchell (ed.), Writings and Speeches, VIII, 68, 72.

${ }^{35}$ Mark Goldie, "Tory Political Thought, 1689-1714" (PhD diss., Cambridge, 1978), 328; J. G. A. Pocock, The Ancient Constitution and the Feudal Law: A Reissue with Retrospect (Cambridge, 1987), 381. 
Bohun and Thomas Long, as well as by the Whig Charles Blount, who had all relied upon Grotius to justify a limited right of resistance, as had de facto theorists like Anthony Ascham earlier in the seventeenth century. ${ }^{36}$ In Book I of De Iure Belli ac Pacis (1625) Grotius admitted that even some of the laws of God carried a tacit exception in cases of extreme and imminent peril, though in no case would this be defensible if consideration of the common good were to be abandoned. On such minimalist grounds resistance would be justified against a ruler who had renounced his governmental authority, alienated his kingdom, or otherwise made himself an enemy to the people. ${ }^{37}$ Stripped of its explicitly Grotian roots, though maintaining the appeal to self-preservation, this argument provided the Whig managers of Sacheverell's impeachment with just the weapon they needed to combat the doctrine of non-resistance without raising the specter of a general and unrestricted right of rebellion..$^{38}$ Burke quoted the transcript of the Sacheverell trial at length in the Appeal from the New to the Old Whigs (1791) to show (in Robert Walpole's words) that only "the utmost necessity ought ... to engage a nation, in its own defense, for the preservation of the whole." 39

During the debate on the French Revolution, reason of state in the Grotian tradition provided Burke with an argument to show that the events of 1688 (in England) and 1789 (in France) were similar in that each presented a case of imminent danger that justified armed intervention and hence fulfilled the conditions of "necessity." This argument from necessity thereby supplied Burke with a weapon against those English Jacobins who assimilated the French Revolution to the Glorious Revolution, and it helped him to show that 1789 was indefensible for just the same reasons that 1688 had been justifiable. Burke could then argue that the French Revolution was uniquely threatening, because it jeopardized the true interests of the states of Europe which were the basis of their natural reasons of state. On these grounds, a crusade against the French Revolu-

$\rightarrow$ Mark Goldie, "Edmund Bohun and Jus Gentium in the Revolution Debate, 1689-1693," The Historical Journal, 20 (1977), 569-86; John M. Wallace, Destiny His Choice: The Loyalism of Andrew Marvell (Cambridge, 1968), 32-35. Anthony Ascham, A Discourse: Wherein is Examined What is Particularly Lawful during the Confusions and Revolutions of Government (London, 1648) was republished as A Seasonable Discourse..., in 1689.

${ }^{37}$ Hugo Grotius, De Iure Belli ac Pacis (1625), I. 4. 7-14, cited for example by [Charles Blount,] The Proceedings of the Present Parliament Justified by the Opinion of the Most Judicious and Learned Hugo Grotius (London, 1689); [Thomas Long,] The Historian Unmask'd (London, 1689), 22, 35.

${ }^{38}$ Geoffrey Holmes, The Trial of Dr Sacheverell (London, 1973), 139; Peter N. Miller, Defining the Common Good: Empire, Religion and Philosophy in Eighteenth-Century Britain (Cambridge, 1994), 79-87.

${ }^{39}$ Burke, An Appeal from the New to the Old Whigs (1791), in Daniel E. Ritchie (ed.), Edmund Burke, Further Reflections on the Revolution in France (Indianapolis, 1992), 131; for Burke's use of the trial see ibid., 124-44. 
tion would be "the most clearly just and necessary war, that this or any other nation ever carried on," 40 in accordance with the principles of the law of nations laid down by the Swiss jurist Emerich de Vattel. For Burke the crucial distinction was that England before 1688 was like France after and not before 1789 . Though the English Jacobins wanted to see the French republicans as the equivalent of the Whigs, for Burke they were not only the equivalent of the Jacobites but were in fact more like Louis XIV in their desire for universal monarchy.

Burke's appeal to necessity revealed the conceptual difference between the Glorious Revolution and the French Revolution. The former had been limited, strategic, and constrained precisely by the principle of salus populi; the latter set fair to unleash illimitable consequences as a result of its unprincipled and unrestricted reasons of state that would endanger the integrity of all states. This, at least, was the direction of Burke's argument in the years following the publication of the Reflections and marked a shift in his conception of reason of state between 1790 and 1793 . However, the fundamental argument, derived from necessity and based upon vestiges of the Roman and neo-Roman theory of reason of state, was contained in the Reflections itself. The Glorious Revolution and the French Revolution could be distinguished according to the true and false appeals to necessity each had inspired. Within the terms of the ius gentium England in 1688 and France after 1793 became conceptually equivalent because each state was internally divided, each was threatened by or itself threatened an imminent danger, and hence each could justifiably necessitate armed intervention. The distinction lay in the fact that France after 1793 (under the militant, oppressive and outwardly aggressive Directory) was equated with England in 1688 (under the rule of the tyrannical James II). As Burke put it in a startling passage of the Reflections, thick with classical allusions and founded upon an argument for conquest that was originally Tory, not Whig:

Laws are commanded to hold their tongues against arms; and tribunals fall to the ground with the peace they are no longer able to uphold. The Revolution of 1688 was obtained by a just war, in the only case in which any war, and much more a civil war, can be just. "Justa bella quibus necessaria." ${ }^{41}$

Burke here alluded to two of the most frequently-cited classical mottos justifying force over law -Cicero's maxim silent leges inter armas (Pro Milone, IV. 11) and the speech of Pontius the Samnite in which he argued that the Roman

${ }^{40}$ Burke, A Letter to a Noble Lord (1796), in Writings and Speeches, ed. McDowell, IX, 168.

${ }^{41}$ Burke, Reflections on the Revolution in France, Writings and Speeches, ed. Mitchell, VIII, 80 . 
rejection of the Samnites' conciliatory overtures after the battle of the Caudine Forks justified them in going to war on grounds of necessity: iustum est bellum, Samnites, quibus necessarium (Livy, Histories, IX. 1. 10). In De Iure Belli ac Pacis Grotius had similarly argued that only the municipal laws of a particular community are "silent ... in the midst of arms" while the natural law remains in force. Grotius further argued that anyone who has given another just cause for war cannot claim to be acting defensively when they are attacked; just so the Samnites were justified in attacking the Romans after the battle of the Caudine Forks. ${ }^{42}$ When Roman implacability demanded extreme measures in response, war became a necessity, and arms became lawful for those who were deprived of all other hope. In just such terms, Burke concluded that the intransigence of James II had been a similar "case of war, and not of constitution," "an extraordinary question of state, and wholly out of law." ${ }^{43}$

External intervention, in this case by the Protestant Prince of Orange and his army, had been justified in England's internal affairs, as a civil war outside the bounds of municipal law became a public war between two princes under the principles of the ius gentium. In such a contest victory generated a legitimate appeal to conquest. On these grounds it was possible to see William's intervention in 1688 as an example of a just war and his victory over James as a legitimate act of conquest. ${ }^{44}$ It is possible that Burke here was thinking primarily as an Irishman: the Williamite War of 1689-91 that marked the Irish phase of the Glorious Revolution was indeed a war of conquest, as the bloodless standoff between James II and the future William III had hardly been in England. ${ }^{45} \mathrm{How}-$ ever, more easily documented is Burke's debt here to Vattel. In Le Droit des Gens (1758) Vattel argued that every foreign power had a right to aid an oppressed people if insupportable tyranny had driven them to rebellion, just as "[t]he English justly complained of James II" in 1688. "Whenever matters are carried so far as to produce a civil war, foreign powers may assist that party which appears to them to have justice on its side," moreover, "every foreign power has a right to succour an oppressed people who implore their assistance." On these grounds William of Orange had justly intervened on the side of the injured parties, the people of England. ${ }^{46}$

${ }^{42}$ Grotius, De Iure Belli ac Pacis, "Prolegomena" 26; II. 1. 18; and see David J. Bederman, "Reception of the Classical Tradition in International Law: Grotius's De Jure Belli ac Pacis," Grotiana, 16/17 (1995/96), 32.

${ }^{43}$ Burke, Reflections on the Revolution in France, in Writings and Speeches, ed. Mitchell, VIII, 80.

${ }^{44}$ Martyn P. Thompson, "The Idea of Conquest in the Controversies over the 1688 Revolution," JHI, 38 (1977), 33-46; Mark Goldie, "Charles Blount's Intention in Writing King William and Queen Mary Conquerors (1693)," Notes and Queries, 223 (1978), 527-32.

${ }^{45}$ The argument that Burke's divided Irishness inflected the whole course of this political thinking is the burden of Conor Cruise O'Brien, The Great Melody: A Thematic Biography and Commented Anthology of Edmund Burke (London, 1992).

${ }^{46}$ Emerich de Vattel, Le Droit des Gens (Neuchâtel, 1758), II. 4. 56; III. 18. 296. 
Vattel's use of the Glorious Revolution to justify intervention by foreign powers and Burke's argument that the Revolution presented a case of just war were in fact the same argument, each with the conclusion that 1688 had been a just war precisely because intervention from outside had been justified according to Vattel's criteria. Burke used just this argument, with direct support from Vattel, in Thoughts on French Affairs (1791) to show that "[i]n this state of things (that is in the case of a divided kingdom) by the law of nations, Great Britain, like every other Power, is free to take any part she pleases." "For this," he had earlier counselled his son, "consult a very republican writer Vattell." 47 This appeal to Vattel harked back to an earlier debate on the morality of war, when - in the case of British capture of the Dutch island of St Eustatius in 1781 during the American War- Burke had invoked "Vattel as being the latest and best [exponent of natural law], and whose testimony he preferred; because, being a modern writer, he expresses the sense of the day in which we live." ${ }^{\prime 8}$ In the case of the French Revolution, however, the question of justice was more vexed and controvertible. According to Vattel, it was "a very celebrated question, and of the highest importance" whether the aggrandisement of a neighboring power could be a sufficient and just reason for war. ${ }^{49}$ Although Grotius and later Wolff had specifically argued that it could never be a just grounds for war "to take up arms in order to weaken a growing power" simply because it might become a source of danger, ${ }^{50}$ Vattel disagreed, and provided Burke with just the reason-ofstate argument he needed to justify a holy war against the Directory. Vattel argued that the safety of a state could be so threatened by a looming neighbor that it would be just to anticipate aggression in the interests of the liberty and order of the whole of Europe, as had been the case during the War of the Spanish Succession. ${ }^{51}$

He argued further that modern Europe was now a kind of republic in which all of the formerly separate nations were bound together by the ties of common interest. The balance of power was the safeguard of those common interests and provided the means of guaranteeing liberty for Europe. A purely utilitarian cal-

${ }^{47}$ Edmund Burke, Thoughts on French Affairs (1791), in Ritchie (ed.), Further Reflections on the Revolution in France, 207; Burke to Richard Burke, Jr., 5 August 1791, in The Correspondence of Edmund Burke: VI July 1789-December 1791, ed. Alfred Cobban and Robert A. Smith (Cambridge, 1967), 317.

${ }^{48}$ Edmund Burke, "Speech on the Seizure and Confiscation of Private Property in St Eustatius," 14 May 1781, in The Parliamentary History of England from the Earliest Times to 1803 (36 vols.; London, 1806-20), XXII, col. 231; and see Ronald Hurst, The Golden Rock: An Episode of the American War of Independence: 1775-1783 (London, 1996).

${ }^{49}$ Vattel, Droit des Gens, III. 3. 42.

${ }^{50}$ Grotius, De Iure Belli ac Pacis, II. 1. 17; II. 22. 5; Christian Wolff, Jus Gentium Methodo Scientifica Pertractatum (1749), $\S 640,651-52$; Alfred Vagts and Detlev F. Vagts, "The Balance of Power in International Law: A History of an Idea," American Journal of International Law, 73 (1979), 562; Tuck, Rights of War and Peace, 189-90.

${ }^{51}$ Vattel, Droit des Gens, III. 3. 42-44. 
culation would not be enough to justify preventive aggression, and only a preemptive response to a threatened injury could be sufficient justification for war. Confederacies might be the best means of defending against such injuries, but if they failed, an evidently aggressive power which threatened the liberties of Europe should be opposed and weakened in the interests of the great commonwealth and in accordance with justice and probity. ${ }^{52}$ Michael Walzer has taken Burke to be the opponent and Vattel the proponent of intervention to uphold the balance of power that maintained the stability of the European "republic"; however, whatever Burke's views may have been in 1760, by 1793 he had come to agree with Vattel that such intervention in defense of the balance of power was justifiable..$^{53}$

Vattel's key historical example of such justifiable precaution was the War of the Spanish Succession. In that war, as Whigs had argued at the time and as Vattel agreed half a century later, Louis XIV had presented a dire threat to the whole European order by his designs for universal monarchy ${ }^{54}$ Because Burke similarly saw 1789 in the light of 1688 , he judged the War against the Directory to be conceptually equivalent to the War of the Spanish Succession. The Treaty of Utrecht that had ended that war enshrined the balance of power as the central regulating principle of the international order in opposition to the threat of universal monarchy from a power such as Louis XIV's France. Reason of state after 1713 therefore made preventive aggression justifiable in defense of the balance against aspiring universal monarchs. The Whiggish idiom of universal monarchy and the memory of the wars that had spawned it clearly lay behind Burke's warning in the Letters on a Regicide Peace that "France, on her new system, means to form a universal empire, by producing a universal revolution." 55 This was the logical successor to Burke's argument in the Reflections that the French Revolution and its aftermath should be seen in light of the Glorious Revolution. The analogy was useful precisely because the common maxims of European civilization and security so menacingly threatened by the "new

${ }^{52}$ Vattel, Droit des Gens, III. 3. 44, 47-49.

${ }^{53}$ Michael Walzer, Just and Unjust Wars (New York, $1992^{2}$ ), 76-80, quoting Burke's Annual Register, 3 (1760), 2; and see Gaetano L. Vincitorio, "Edmund Burke and the First Partition of Poland: Britain and the Crisis of 1772 in the "Great Republic," Crisis in the "Great Republic": Essays Presented to Ross J. Hoffman, ed. Gaetano L. Vincitorio (New York, 1969), $33-42$.

${ }^{54}$ John Robertson, "Universal Monarchy and the Liberties of Europe: David Hume's Critique of an English Whig Doctrine," Political Discourse in Early Modern Britain, ed. Nicholas Phillipson and Quentin Skinner (Cambridge, 1993), 356-68.

${ }^{55}$ Edmund Burke, Third Letter on a Regicide Peace, in McDowell (ed.), Writings and Speeches, IX, 340. Thomas L. Pangle and Peter J. Ahrensdorf, Justice Among Nations: On the Moral Basis of Power and Peace (Lawrence, Kan., 1999), 184, argue that "it is in his loathing of universal empire that Burke stands furthest, in his conception of international relations, from his otherwise favorite authority, the Roman patriot Cicero," though this fails to distinguish between differing conceptions of "universal empire" (on which see, for example, Cicero, De Officiis, II. 27). 
system" of the French and upheld by Vattel. ${ }^{56}$ Vattel's argument was partly the product of the opening phase of the Seven Years' War, and in it he assumed - as Bolingbroke, Hume, Robertson, and Gibbon also did $^{57}$ - that the balance of power as enshrined in the Treaty of Utrecht was the basis of the international order. Burke returned to the same origin to argue that, "[i]f to prevent Louis the XIVth from imposing his religion was just, a war to prevent the murderers of Louis XVIth from imposing their irreligion upon us is just." 58

The Revolutionary Wars would in due course shatter the European balance of power and, as Paul Schroeder has argued, thereby irreversibly transform European politics. ${ }^{59}$ Burke was the prophet of the transformation, and he foresaw it with the help of Vattel, in accordance with post-Utrecht reason of state. In the Remarks on the Policy of the Allies (1793) he cited Vattel to show that the right to intervene became a duty in certain circumstances, according to "whether it be a bona fide charity to a party, and a prudent precaution with regard to yourself." As Burke showed with an appendix of extracts from Vattel, intervention against France would be a "prudent precaution" for all European states precisely because the French republic presented an unprecedented threat to their natural reasons of state - their interests, their security, and above all their shared political maxims as partners in the commonwealth of Europe ${ }^{60}$ Proximity, vicinity, and legitimate apprehension of danger therefore justified intervention: as Burke crisply summarized this position in 1796, "I should certainly dread more from a wild cat in my bed-chamber, than from all the lions that roar in the deserts beyond Algiers."

${ }^{56}$ See J. G. A. Pocock, Barbarism and Religion, I: The Enlightenments of Edward Gibbon, 1737-1764 (Cambridge, 1999), 109-13, 133-34, 138-39, and Barbarism and Religion, II: Narratives of Civil Government (Cambridge, 1999), 170, 219, 275-77.

${ }^{57}$ Bolingbroke's Defence of the Treaty of Utrecht, ed. G. M. Trevelyan (Cambridge, 1932); David Hume, "Of the Balance of Power" (1752), in Eugene F. Miller (ed.), Hume, Essays: Moral, Political and Literary (Indianapolis, 1987), 338-41; Frederick G. Whelan, "Robertson, Hume, and the Balance of Power," Hume Studies, 21 (1995), 315-32; Jeremy Black, "Gibbon and International Relations," Edward Gibbon and Empire, ed. Rosamond McKitterick and Roland Quinault (Cambridge, 1997), 225-28.

${ }^{58}$ Edmund Burke, First Letter on a Regicide Peace (1796), in Writings and Speeches, ed. McDowell, IX, 238; compare Burke, A Letter to a Member of the National Assembly (1791), in Writings and Speeches, ed. Mitchell, VIII, 306: "The princes of Europe, in the beginning of this century, did well not to suffer the monarchy of France to swallow up the others. They ought not now, in my opinion, to suffer all the monarchies and commonwealths to be swallowed up in the gulph of this polluted anarchy."

${ }^{59}$ Paul W. Schroeder, The Transformation of European Politics, 1763-1848 (Oxford, 1994).

${ }^{60}$ Edmund Burke, Remarks on the Policy of the Allies (1793), in Writings and Speeches, ed. Mitchell, VIII, 474; the "Appendix" of extracts from Vattel is inexplicably omitted from this edition. For a fragment of Burke's working notes on Vattel see Sheffield City Libraries Wentworth Woodhouse Muniments, 10/27, (passage transcribed from Vattel, Droit des Gens, II. 12. 196-97, printed in Burke, Remarks on the Policy of the Allies [London, 1793], 207-9).

${ }^{61}$ Burke, First Letter on a Regicide Peace in Writings and Speeches, ed. McDowell, IX, 259 (arguing against Charles James Fox's claim that the French republic should be tolerated on the same grounds that justified keeping a consul in Algiers). 
Burke argued in the Thoughts on French Affairs (1791) that, though there had been many internal revolutions within the governments of Europe, none (not even the Glorious Revolution) had effects beyond their own limited territories. However, he added:

The present Revolution in France seems to me to be quite of another character and description; and to bear little resemblance or analogy to any of those which have been brought about in Europe, upon principles merely political. It is a Revolution of doctrine and theoretick dogma. It has a much greater resemblance to those changes which have been made upon religious grounds, in which a spirit of proselytism makes an essential part.

The last Revolution of doctrine and theory which has happened in Europe, is the Reformation ... [the] effect [of which] was to introduce other interests into all countries, than those which arose from their locality and natural circumstances. ${ }^{62}$

To introduce alien interests, as the Reformation had done and as the Revolution threatened to do, and in particular to introduce alien interests which claimed universal applicability, such as justification by faith or the rights of man, dissolved the necessary connection between a state's natural situation and the idiomatic interests it generated. Thereby, "if they did not absolutely destroy, [they] at least weakened and distracted the locality of patriotism" ${ }^{\prime 63}$ and with it the determinative, organic reasons of state.

Throughout the 1790s and particularly during the opening years of the war against the Directory Burke maintained that Britain and its allies were engaged against France in a "religious war," "a moral war" against the "armed doctrine" of "a sect aiming at universal empire." ${ }^{\circ 4} \mathrm{Of}$ course he was not alone in arguing that the war against the Directory was a war of religion; such arguments were a staple of Anglican polemic during the early years of the war. This "new and unheard-of scheme of conquest and aggrandizement ... the total subversion of every lawful government, of all order, of all property, and of all established religion" could only be resisted by a "just and necessary war," argued Walker King at Gray's Inn in 1793. "The nation with whom we are at war," Charles

${ }^{62}$ Burke, Thoughts on French Affairs, in Further Reflections on the Revolution in France, ed. Ritchie, 208 (Burke's emphases).

${ }^{63}$ Burke, Thoughts on French Affairs, in Further Reflections on the Revolution in France, ed. Ritchie, 209.

${ }^{64}$ Burke, Remarks on the Policy of the Allies (1793), in Writings and Speeches, ed. Mitchell, VIII, 485; Fourth Letter on a Regicide Peace (1795-96), in Writings and Speeches, ed. McDowell, IX, 70; First Letter on a Regicide Peace (1796), in Writings and Speeches, ed. McDowell, IX, 199; Second Letter on a Regicide Peace, in Writings and Speeches, ed. McDowell, IX, 267. 
Manners Sutton told the members of the House of Lords in the following year, "is professedly a heathen nation; and unless it shall please God to spare his people, our laws, and liberty, and religion, are inevitably lost." Such "a war against all Religion, carried on in the very center of Christendom, by a people hitherto numbered among the most enlightened of nations," George Gordon informed his audience in Exeter on the same day, "is a novelty in history"; to oppose it would demand "a war of stern necessity, and consequently of the strictest justice." ${ }^{\prime 65}$ However, Burke's charge of universal empire hinted that the French republic was as great a threat to the common maxims of the great republic of Europe as Louis XIV had been almost a century earlier. In his international theory as in his political theory Burke remained true to the ideological inheritance of English Whiggism not least because he drew so heavily on Vattel, whose anglophilia was decidedly Whig in complexion ${ }^{66}$ and whose doctrines of the law of nations were directed to the same end as Burke's, that is, to the defense of the European balance of power and the new international reasons of state originally guaranteed by the Treaty of Utrecht.

Burke was more than just a conspiracy theorist of the Revolution (though he did sympathize with those, like the Abbé Barruel, who saw free-thinkers, Freemasons, and Jews behind the events of 1789 and thereafter); ${ }^{67}$ he was also more than simply the most frantic and prominent apologist for Anglicanism in the face of French revolutionary atheism (though there is truth in that view, too). He was in fact a classic early modern theorist of reason of state within the natural-law tradition revived by Grotius and revised by Vattel. Reason of state made the internal and external realms of state policy mutually intelligible for Burke; it provided him with an argument to ensure security in extremity without destroying security, property, or law; and it provided the most persuasive analysis of the collapse of the European state system, the failure of the balance of power, and the desperate need for self-preservation compelled by the French Revolution. ${ }^{68}$ This strain within Burke's political thought showed that reason of state had not

${ }^{65}$ Walker King, Two Sermons, Preached at Gray's-Inn Chapel; On Friday, April 19, 1793 (London, 1793), 12, 10-11; Charles Manners Sutton, A Sermon Preached Before the Lords Spiritual and Temporal in the Abbey Church of St. Peter, Westminster, on Friday, February 28, 1794 (London, 1794), 14; George Gordon, A Sermon, Preached in the Cathedral Church of St. Peter, Exeter, On Friday, February 28, 1794 (Exeter, 1794), 10, 26.

${ }^{66}$ See Vattel, Droit des Gens, I. 2. 24; I. 4. 39; I. 6. 76; I. 8. 85, 87, etc.

${ }^{67}$ J. M. Roberts, "The Origins of a Mythology: Freemasons, Protestants and the French Revolution," Bulletin of the Institute of Historical Research, 44 (1971), 78-97; Amos Hofman, "The Origins of the Theory of the Philosophe Conspiracy," French History, 2 (1988), 152-72; Darrin M. McMahon, Enemies of the Enlightenment: The French Counter-Enlightenment and the Origins of the European Right, 1778-1830 (Oxford, forthcoming).

${ }^{68}$ Peter Onuf and Nicholas Onuf, Federal Union, Modern World: The Law of Nations in an Age of Revolutions, 1776-1814 (Madison, 1993), 8-9, 188-89. 
lost its rational basis long before 1789 (pace Reinhard Koselleck), ${ }^{69}$ it also demonstrated that it was not a necessary consequence of reason-of-state theory that it should separate a state's domestic maxims from its foreign policies (pace Meinecke) $;{ }^{70}$ and it proved, to Burke's satisfaction (as it no doubt would have been to Vattel's, too), that reason of state was not by definition the enemy of "law or innate moral principles" (pace almost everybody). ${ }^{71}$

However, Vattel and Burke stood at the end of this tradition of reason of state. After all, it was in the context of the same late eighteenth-century wars that Kant and Bentham produced their respective plans for perpetual peace, each of whom attempted to conceive cooperative, transparent international norms and institutions that would render such reason of state inoperable and obsolete. ${ }^{72}$ Both also questioned the Whiggishly self-congratulatory account of the Glorious Revolution on whose historical foundations Burke's theory rested, Kant because it exemplified both a "monstrous" appeal to "a right of necessity" (ius in casu necessitatis) and a tacit, standing right to rebellion without restriction, Bentham because he could not see it as beneficial for the interest of the nation (rather than to the "particular interest of the aristocratical leaders in the revolution"). ${ }^{73}$ The Kantian categorical imperative and Bentham's greatest happiness principle provided competing but equally fatal alternatives to this tradition of reason of state; their anathematization of it opened up that gulf between morality and politics out of which Meinecke's instrumentalist account-and, consequently, almost everyone else's - emerged. To place Burke on one side or the other of this argument has always risked distorting historical accounts of his thought, whether in the political sphere or the international realm; it has also sharpened the distinction between these two arenas in ways which neither early modern theorists of reason of state nor Burke himself would have recognized. Burke's place in the history of international thought should therefore be assimilated more closely to his position in the traditions of political thought, as a standing reproach to procrustean taxonomies and overhasty appropriations.

\section{Columbia University.}

${ }^{69}$ Reinhard Koselleck, Critique and Crisis: Enlightenment and the Pathogenesis of Modern Society, Eng. tr. (Cambridge, Mass., 1988), 17, 39.

${ }^{70}$ Meinecke, Machiavellism, 13.

${ }^{71}$ In this case, Boucher, "The Character of the History of Philosophy of International Relations and the Case of Edmund Burke," 135.

${ }^{72}$ Immanuel Kant, "Perpetual Peace: A Philosophical Sketch" (1795), in Kant: Political Writings, ed. Hans Reiss (Cambridge, 19912), 93-130; Jeremy Bentham, "Pacification and Emancipation" (1786-89), Bentham MSS XXV, University College London, printed (in a heavily edited version) as "A Plan for an Universal and Perpetual Peace;" in The Works of Jeremy Bentham, ed. John Bowring (11 vols., London, 1843), II, 546-60; Stephen Conway, "Bentham versus Pitt: Jeremy Bentham and British Foreign Policy 1789," The Historical Journal, 30 (1987), 803-9.

${ }^{73}$ Immanuel Kant, "On the Common Saying: 'This May be True in Theory, But it Does Not Apply in Practice"' (1793), in Kant: Political Writings, ed. Reiss, 81, 83-84; Jeremy Bentham, "The Book of Fallacies" (1818), in Bowring (ed.), Works of Jeremy Bentham, II, 447-48. 